\title{
THE USEFULNESS OF TRADE EXHIBITION AND MODERATION EFFECT OF SIZE ON THE GROWTH OF MICRO AND SMALL ENTERPRISES
}

\author{
Nyakujanga Sabato \\ (PhD student) \\ Dr. Janeth Isanzu (PhD) \\ Open University of Tanzania, Faculty of Business Management \\ Dr. Saganga Kapaya (PhD) \\ Open University of Tanzania, Faculty of Business Management \\ http://doi.org/10.35409/IJBMER.2020.3206
}

\begin{abstract}
The study analysed data from 220 cluster sampled micro and small enterprises from textile, food vending, soap making, services, poultry, food processing and handcraft. Based on Tanzania MSE's definition firm growth and contingent perspectives were used to determine the influences of MSE's trade exhibition in the context of business sizes. The targeted MSE's were those whose their owner managers received the support link to exhibition. Items with five scaling points statistically were tested using SPSS V22 in addition of process software for moderation test. Descriptive data are presented while regression analysis was adopted to test three hypothesis. Regression analysis output indicated significant $(\mathrm{p}=0.000)$ positive influences of facilitation to idea generation and network extension from exhibition on MSE's growth. On the other hand business size indicated insignificant in affecting the relationship of exhibition variables MSE's on growth. Building on the results its good for policy makers need to develop strategies that will assist MSE's exhibition costs minimization in relation to their financial structures and constrain and hence encouraging more studies that may cover more variables in the construct to feed more inputs to our current knowledge.
\end{abstract}

Keyword: Exhibition and MSE's growth.

\section{INTRODUCTION}

Worldwide micro and small enterprises acknowledged as a supporter and drivers of economic growth and prosperity. It's vital role on generation sustainable job creation, promotion of entrepreneurial environment and income generation is undisputable (Mulyantini,2020). Furthermore, their nature of acting informal is increasingly being recognized by many economies and donors community based on the facts that it is the venue of breeding ground in the process contributing to the reduction of poverty (Lesuruan and Kihara, 2017: Lesuruan,2018 Saidi and Abideen 2017:Terefe,2018). The initiated interventions to enable operators solve the Micro and Small Enterprise (MSE) problems have been underway( Dladla and Mutambara,2018: Terefe, 2018). To ensure market accessibility the assistance includes expansion of support through trade exhibitions facilitation locally and internationally (Anna,2018). 
Competing in a current business environment require substantial amount of funding and experiences where most MSE's may experiences handles in reaching market due to lack of capital and skills(Akman and Dagdeviren,2018). The improved link for market access through trade exhibition event assists MSEs to present products and services to a wider audience of potential customers, partners and investors(Ummulkulthoum1 and Jianhua, 2017). The connection of owners and managers with each other and potential business resources, generation of new clients and referrals for more sales has been identifies as the benefits associated with trade exhibition facilitation (Aikaeli, 2012: Mori,2014; Kemp,2013).

The event is one of the most effective and efficient atmospheres and venues for increasing brand awareness and introduction of new product in the market. Other is an opportunity for new business ideas conception with constant soliciting customer feedbacks (AUMA, 2013: Loewe,et al, 2013). It however a very relevant opportunity for exchange of goods and services and motivator for employment opportunities and hence encouraging manufacturers to compete favourably for market shares (Olawale et al,2018).

MSE's have experienced values exchanges as one of the benefits obtained when they participate in trade exhibition. This comes by learning the best practices in their line of businesses. Also the reap of technical knowhow from other related companies is vital ingredient for MSE's changes in sales, product and services and formalization (Olawale et al,2018). For MSE's that participate will manage to meet face to face with other companies from different economies for exchange information during Business to Business meeting and hence obtaining views from other exhibitors that are not direct related to firms business nature.

The event assists MSE's firms to increase level of turnover, learning what others are doing and emulate best practices, increase level of expertise in production and provision of services business, improving packaging of products, and understanding about market and what exactly customers need (Priyanath, \& Premaratne, 2014: Akman and Dagdeviren, 2018).

In Tanzania the intervention is very vital in the development of market and improvement creativity, networking, access to market information idea and network (Mbura and Bambaganya,2015). Exhibition an important opportunity to communicate values to the audience at low costs (Stokes and Wilson, 2006). Through this facilitation to trade exhibition and direct access to friends, fellow members, new customers, investors, competitors, regulatory and suppliers there is a lack of information on how trade exhibition influences changes in sales, product and services and transformation from informal to formal practices.

\subsection{Definition of Micro and Small Enterprises}

The definition for micro and small enterprises varies from country to country. What is identified or categorized as micro enterprise in one country may be considered as a small enterprise in other country (Hatten,2012). Some definitions focus on numerical parameters in order to differentiate between smaller, medium and larger business with division of quantitative and non-qualitative. Quantitative thresholds are important because they are used to determine the eligibility of business for certain type of grant or other assistance. For non-quantitative the 


\section{International Journal of Business Management and Economic Review}

Vol. 3, No. 05; 2020

ISSN: 2581-4664

essence is to differentiate the characteristics of business by most easily recognizing them in their operations (Kule, 2014).

The most commonly used criteria to define micro and small enterprises are the number of employees, total net sales and investment level. Since this is the mostly frequently (employment) adapted and here again different economies variation in defining the upper and lower size limit of micro and small scale enterprises differs (Terefe,2018).

In a developed countries, criteria are different from those used above. Nevertheless, the most common criterion is still the number of employees although this may exceed that used in developing countries particularly Africa (Sarr, 2019). It remain to the fact that, what may be categorized as micro enterprise in one economy may be considered as a small enterprise in other(Terefe,2018).

However, we can also classify this sector in economy into two major groups, first are those operating in compliance with regulations and second are those that operates informally with lack of compliance status.

In Tanzanian definition, the businesses with single employee to four and the capital investment ranging from zero to five millions are regarded to be micro. Small ones are those with four to forty nine employees operating with capital that stands at the tune of five to two hundred millions. As for medium are those having between fifty and ninety nine employees with capital threshold of two hundred to eighty hundred million. Above that the business is considered larger (SME's policy, 2003; Anderson, 2012; Olomi \&Mori, 2015).

For the purposes of directing its policy and programmers support, in the economy the study has adopted a definition of micro, small and medium/large enterprises based on invested capital and the number of employees (Mori and Olomi,2014: Andersorn,2017).

Table 1 - Definition of Micro, Small, Medium and Lager Enterprises

\begin{tabular}{|l|l|l|}
\hline Categories & Number of employees & Capital investment (Tsh) \\
\hline Micro enterprises & $1-4$ & 0 to 5 million \\
\hline Small enterprises & $5-49$ & Above 5 million to 200million \\
\hline Medium enterprises & $50-99$ & Above 200 million to 8oomillion \\
\hline Larger enterprises & $100+$ & Above 800million \\
\hline
\end{tabular}

Source, URT / MIT - SME's Policy, (2003). 1 US\$ is Equivalent to Tanzanian

Shillings 2279.24 in 2020)

\subsection{Exhibition}

The organized events that are essentially the point of contacts for relevant information acquisition. Business expose ideas, create product awareness and sales products and services to a wider audience of potential customers, partners and investors (Mulyantini et al, 2020).

On the other hand is the venue where networks are established by means of idea sharing, talking to people and meetings friends. It is also an opportunity to meet fellow members, new 


\section{International Journal of Business Management and Economic Review}

Vol. 3, No. 05; 2020

ISSN: 2581-4664

customers, investors, competitors, regulatory and suppliers. On the other hand it assists communication of business values to the audience at low costs (Stokes and Wilson,2006; Nyamagere and, chimbi2018)). MSEs to present their

\subsection{MSE's growth.}

This is a resource excess with evolutionary development of products, services and strategies to covers the expectations of multiple stakeholders such as owners, corporate, and policy makers (Machado,2016: Schmitt,2018). Growth can happen horizontally or vertically by the way of establishment of more business at the same level, or graduation and transformation of micro to small and small to medium business (Mungai,2012). The excess resources for expansion include those which it own and that which can be redeployed for new and more productive application (Nason and Wiklund, 2018; Rim, and Monia, 2018; Penrose, 1959; Willemse, 2018). Usually is an increase in output or sales and size or improvements in quality as the results of a process of development, akin to the natural biological process in which an interacting series of internal changes lead to increase in size accompanied by changes in the characteristics of the growing object (Olomi, 2003). Contrary to biological analogy is an ability of businesses to take on a corporate existence of their own, independent of their creator and owner's personality after a personal objectives displays significant influence in the direction of expansion for resources expansion (Pernose, 1959: Schwab's, et al,2017).

The understanding of growth in this paper depends on the definition of what the firm or enterprise is how much have it grown in resources, and what it offers on turnover or sales, product and services increase and formalization (Pernose, 1959: Aislabie, 1992, Machado, 2016).

\section{THEORETICAL AND LITERATURE REVIEWS}

Considering Penrose (1959), knowledge is among the most important resources in business and thus becoming essential stepping stones in achieving resources expansion ( Sharafizad and Coetzer,2016: Rennemo \& Bogren, 2017). In Penrosean argument the pursue of new ability for opportunities not only give alternatives but rather ability for managers to interpret contingent environment, in this case current internal resources endowment restriction may cause challenges in the growth path initiative (Woodward,1965: Pervan \& Visic, 2012; Machado, 2016).

This has led to various stakeholders to invest in strategies and measure that assist Micro and small enterprises survival. Measures taken by various governments and other nongovernment institution in the form of trade exhibition facilitation on the one hand, increase the probability of expanding market, while contributing expansion through control over potentially valuable resources (Ramaciotti,et al,2017).

Kirchgeorg et al 2009 and Aikael, 2012 has indicated the important of trade exhibition for firms as the platform for, introduction of new products to a large number of people, the enhancement of goodwill, uncovering potential of customers, promotion of existing products, reinforcement of existing customer relationships, gathering competitors information and general marketing research. The exhibition is an opportunity created via MSE's ability to interact with visitors

Moreover, when they participate they contact in personal with customers at lower cost, as opposed to advertising, they enable MSE's to test their products at the same time marketing 


\section{International Journal of Business Management and Economic Review}

Vol. 3, No. 05; 2020

ISSN: 2581-4664

them appropriately (Ummulkulthoum, \& Jianhua 2017:. Priyanath, \& Premaratne, 2014).

\subsection{Research problem}

Most of the MSE's in developing countries including Tanzania have not harnessed advantages associated with exhibitions. This is because some of them can't afford participation costs, and for several others it is because they don't have exposure to its potential participation gains. The paper intends to determine the role of trade exhibition linkage to micro and small enterprises growth since most of them faces financial limitation to participates in relation to their sizes. .

\subsection{Theoretical gap}

Firm growth asserts firm growth to be the product of idiosyncratic resources including managerial skills, knowledge and unique competences. However the theory suggest managers leaning how to use existing knowledge and skills more efficiently and alternatively use of new knowledge from external sources, but with conditional of internal absorbing capabilities, the according to this perspectives there is a lacks information on which ways intangible capabilities including pertinent information, ideas and networking with other competent stakeholders can be taped from the external sources in case of limitation. Not only that it lacks means of how business may tap intangible capabilities from outside, contingently the perspective does not consider specific contexts of resources size as defined in a given economy.

The objective of the study was to determine the role of exhibition facilitation and moderation effect of size on micro and small enterprises growth.

From the main objective three specific objectives were developed

1. Knowledge gain influences micro and small enterprises growth

2. Extension of network influences micro and small enterprises growth

3. Business size moderates the relationships of at least one of two exhibitions

Variables and micro and small enterprises Growth.

From the objective above three hypotheses are formulated.

H1. Knowledge gain has a positive relationship on micro and small enterprises growth

H2. Extension of network has a positive relationship on micro and small enterprises growth

H3. Business size affect the relationships of at least one of two exhibition indicators and Micro and small enterprises growth.

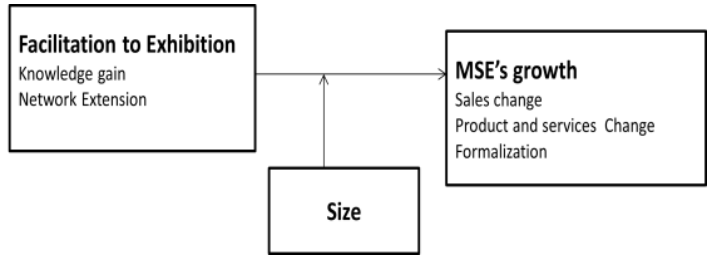

Figure 1. The conceptual framework 
Vol. 3, No. $05 ; 2020$

ISSN: 2581-4664

\section{THE METHODOLOGY}

Quantitatively, positivism guided to offer the ground for the causal relationship between variables test (Krauss, 2005; Saunders, et al, 2016). Firm growth and contingency perspective been a guide to the already establishes laws and principles by the means of survey from 1119 micro and Small enterprises in Arusha, Dar es salaam and Coast regions (Lufumbi,2009).

The causal relationship between two exhibition variables influence on sales, product or service offered and formalization with greater emphasis on quantitative data in the context of specific business sizes was analysed for conclusion (Saunders, et al, 2016 and Thibodeau, 2011).

The cluster sampling process was used to obtain 254 MSE's accessed exhibition facilitation link services from poultry, soap making, handcraft, textile, services, food vending and processing subsectors from 2012 to 2017 in Arusha, Dar es Salaam and Coast regions. The frame consists those who have been in business for a minimum period of two years prior and after receiving the services (Rennemo and Widding, 2017). It builds on the facts that, the period was good in realizing the effects of the links (Premaratne,2002;Stokes and Wilson ,2010: Von Friedrichs and Rennemo,2013).

The sample frame in the study was micro and small enterprises whose their owner's managers. Researcher and two assistants distributed 254 copies to owner's mangers received link from enablis and TASWE. Out of 254 questionnaires only (220) 86\% were successful completed and returned.

The adjustment of tools from previous studies (Ansah, 2016: Crompton, 2012; Mungai,2012; Kazungu et al.,2018) was done on self administered question with closed ended questions . The reliability and factor analysis was done where cronbach coefficiency was .805 and KMO of .782 with Bartlett's test of 413.534 at $.000 \mathrm{p}=$ value. Items with five scaling points statistically were tested using SPSS V22 in addition of process software for moderation interaction test (Hayes, 2012).

\section{DESCRIPTIVE ANALYSIS AND HYPOTHESIS TESTING}

The frequency analysis was done to examine some respondents' characteristics and levels of business growth before and after exhibition linkages services provision.

Table 2 . Respondents characteristics $(n=220)$

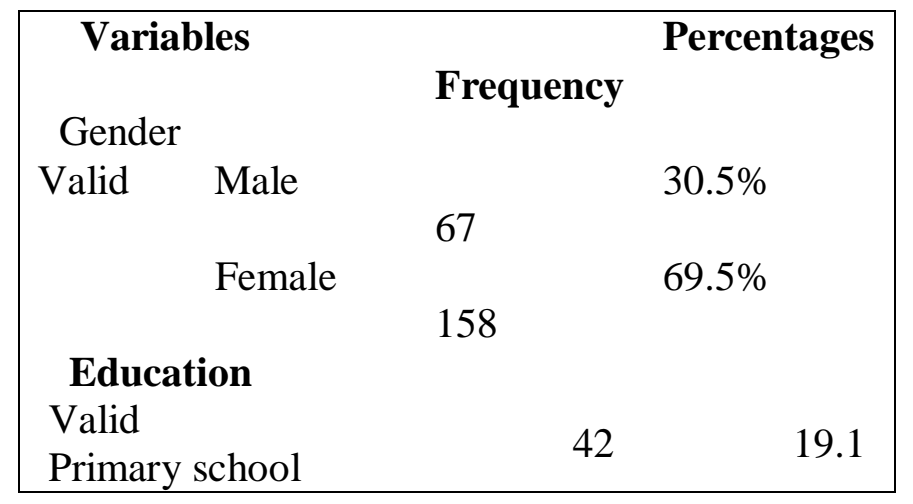


International Journal of Business Management and Economic Review

Vol. 3, No. 05; 2020

ISSN: 2581-4664

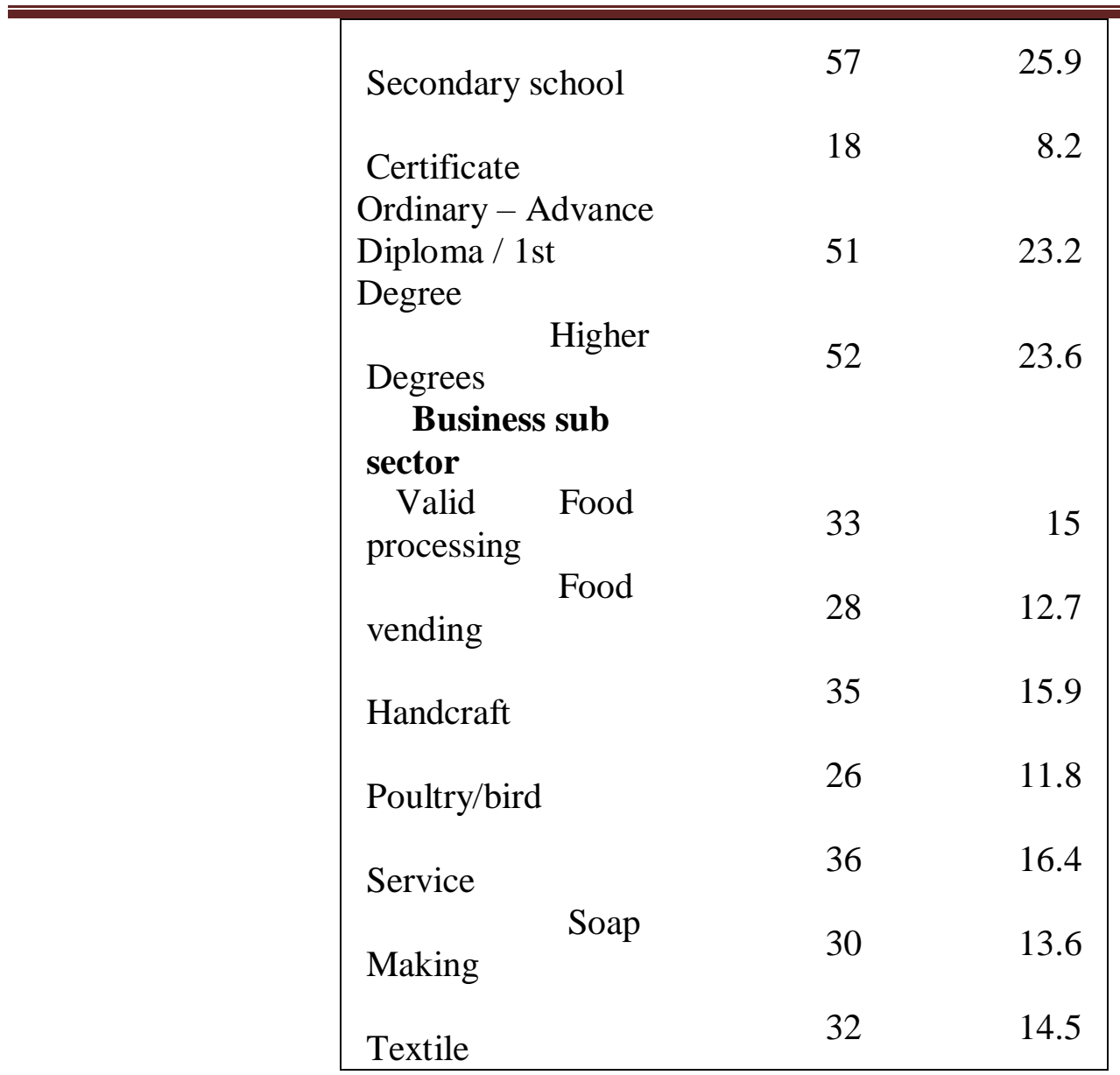

Source: Data analysis, 2020.

Table 3 Growth indicators $(n=225)$

\begin{tabular}{|c|c|c|c|c|}
\hline Sizes & \multicolumn{2}{|c|}{$\begin{array}{l}\text { Before } \\
\text { exhibition } \\
\text { Monthly } \\
\text { average Sales }\end{array}$} & \multicolumn{2}{|c|}{$\begin{array}{l}\text { After } \\
\text { exhibition } \\
\text { Monthly } \\
\text { average } \\
\text { Sales }\end{array}$} \\
\hline & $\begin{array}{l}\text { Frequen } \\
\text { cy }\end{array}$ & $\begin{array}{l}\text { Per } \\
\text { cent }\end{array}$ & $\begin{array}{l}\text { Fre } \\
\text { que } \\
\text { ncy }\end{array}$ & $\begin{array}{c}\text { Perce } \\
\text { nt }\end{array}$ \\
\hline $\begin{array}{l}0-3 \\
\text { Millio } \\
\text { ns }\end{array}$ & 189 & $\begin{array}{l}85 . \\
9\end{array}$ & 89 & 40.5 \\
\hline $\begin{array}{l}3- \\
5 \text { Milli }\end{array}$ & 18 & 8.2 & 83 & 37.7 \\
\hline
\end{tabular}


International Journal of Business Management and Economic Review

Vol. 3, No. 05; 2020

ISSN: 2581-4664

\begin{tabular}{|l|lllll|}
\hline \hline ons & & & & \\
5 to & 10 & 4.5 & 27 & 11.8 \\
$10 \mathrm{mill}$ & & & & \\
ions & 3 & 1.4 & 23 & 10 \\
10 & & & & \\
and & & \\
Above & & &
\end{tabular}

Table 4a. Formalization status before and after exhibition services $(\mathbf{n = 2 2 0})$

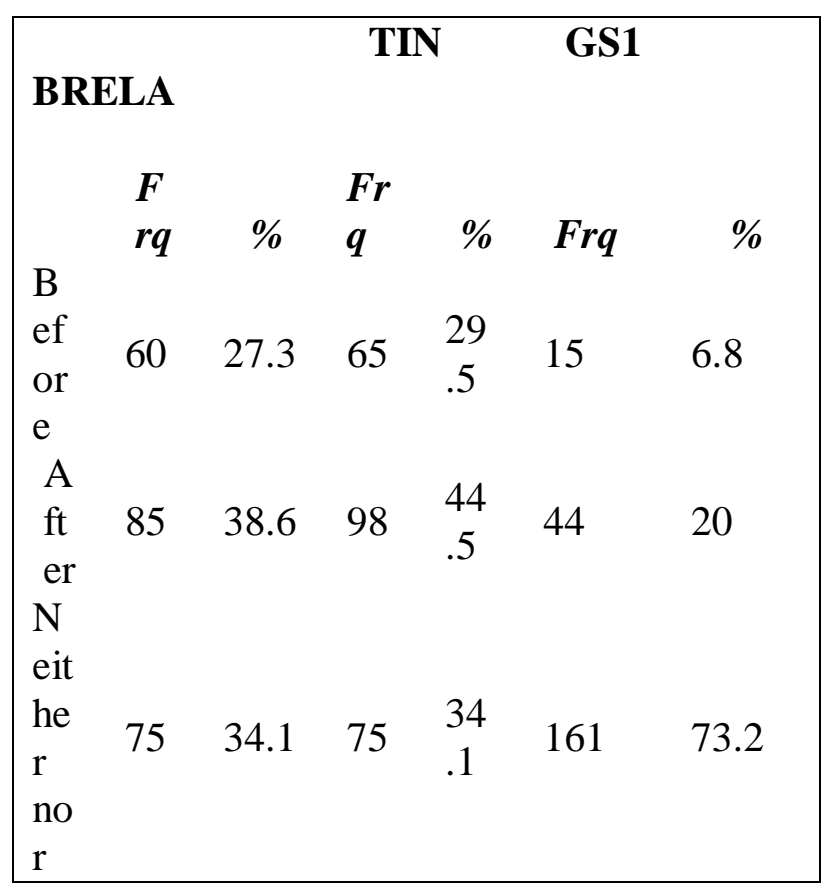

Table 4b. Formalization status before and after exhibition services $(n=220)$

\begin{tabular}{|c|c|c|c|c|c|c|}
\hline \multirow[t]{2}{*}{$R / K$} & & \multicolumn{4}{|c|}{ LOCATION } & $\begin{array}{l}\text { LICE } \\
\text { NSE }\end{array}$ \\
\hline & $\mathrm{Fr}$ & & $F r$ & & $F r$ & \\
\hline & $q$ & $\%$ & $q$ & $\%$ & $q$ & $\%$ \\
\hline $\begin{array}{l}\text { Bef } \\
\text { ore }\end{array}$ & 38 & $\begin{array}{l}17 \\
.3\end{array}$ & 47 & $\begin{array}{r}21 \\
.4\end{array}$ & 62 & 28.2 \\
\hline $\begin{array}{l}\text { Aft } \\
\mathrm{er}\end{array}$ & $\begin{array}{r}10 \\
9\end{array}$ & $\begin{array}{l}49 \\
.5\end{array}$ & 98 & $\begin{array}{r}44 \\
.5\end{array}$ & 81 & 36.8 \\
\hline $\begin{array}{l}\text { Neit } \\
\text { her } \\
\text { nor }\end{array}$ & 73 & $\begin{array}{l}33 \\
.2\end{array}$ & 75 & $\begin{array}{r}34 \\
.1\end{array}$ & 77 & 35 \\
\hline
\end{tabular}


International Journal of Business Management and Economic Review

Vol. 3, No. 05; 2020

ISSN: 2581-4664

Table 5. Number of product and services two years before and after Exhibition

\begin{tabular}{|c|c|c|c|c|c|}
\hline Two Years Befor & & & & Year & \\
\hline Product/Service & Frea & $\%$ & Prod/ services & Frea & $\%$ \\
\hline Valid 0 & 2 & .9 & Valid 0 & 34 & 15.5 \\
\hline 1 & 208 & 94.5 & 1 & 90 & 40.5 \\
\hline 2 & 4 & 1.8 & 2 & 69 & 31.4 \\
\hline 3 & 3 & 1.3 & 3 & 24 & 10.9 \\
\hline 4 & 1 & .5 & 4 & 2 & .9 \\
\hline 11 & 2 & .5 & 6 & 2 & .9 \\
\hline Total 21 & 220 & 100.0 & Total 16 & 220 & 100.0 \\
\hline
\end{tabular}

Source: Data analysis,(2020

The Hypothesis Testing

Table 6 Regression results Model Summary ${ }^{b}$

\begin{tabular}{|l|l|c|r|}
\hline Variables & $\begin{array}{c}\text { R } \\
\text { Squ } \\
\text { are }\end{array}$ & $\begin{array}{c}\text { Adju } \\
\text { sted } \\
\mathrm{R} \\
\text { Squ } \\
\text { are }\end{array}$ & $\begin{array}{r}\text { Std. } \\
\text { Error } \\
\text { of the } \\
\text { Estim } \\
\text { ate }\end{array}$ \\
\hline $\begin{array}{l}\text { KNOWLEDGE } \\
\text { GAIN }\end{array}$ & .320 & .317 & $\begin{array}{r}.7367 \\
8\end{array}$ \\
\hline Network Extension & .240 & .236 & $\begin{array}{r}.7799 \\
5\end{array}$ \\
\hline Interactions & & & $\mathrm{P}$ \\
\hline Knowledge *SIZE & .301 & & $\begin{array}{r}\text { value } \\
(.000)\end{array}$ \\
\hline $\begin{array}{l}\text { Network Extension } \\
\text { * SIZE }\end{array}$ & .222 & & $\begin{array}{r}\mathrm{P} \\
\text { value } \\
(.000)\end{array}$ \\
\hline
\end{tabular}

Table 7. Analysis of variances (ANAOVA)

\begin{tabular}{|lcccc|}
\hline Knowledge & Su & & & \\
gain & $\mathrm{m}$ & & & \\
& of & & & \\
& $\mathrm{Sq}$ & & & \\
& uar & Df & & \\
& es & 1,2 & $\mathrm{~F}$ & Sig. \\
Regression & 55. & 1 & 10 & $.000^{\mathrm{b}}$ \\
\hline
\end{tabular}


International Journal of Business Management and Economic Review

Vol. 3, No. 05; 2020

ISSN: 2581-4664

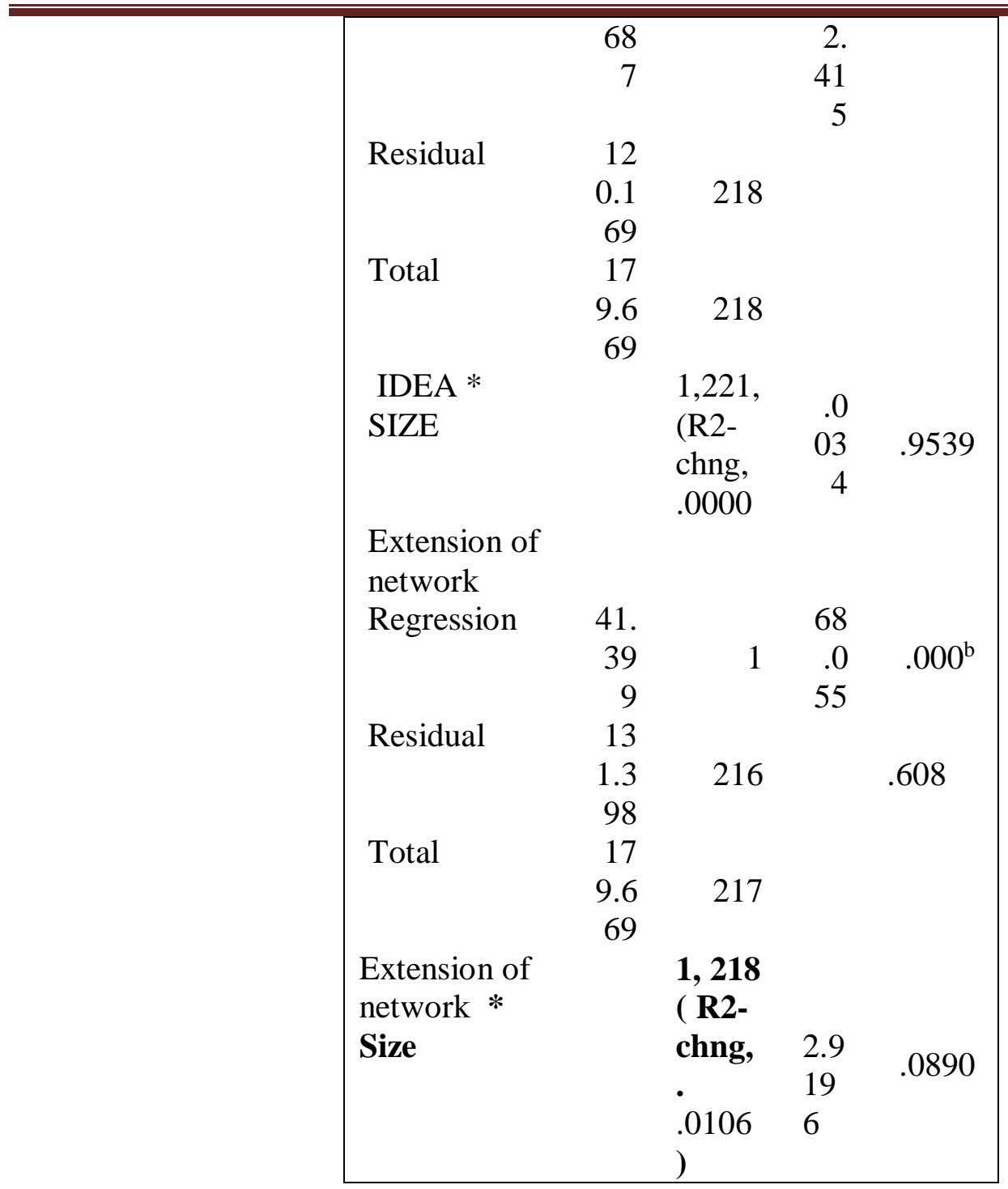

Table 8 Coefficiency of correlation

\begin{tabular}{|l|l|l|l|l|}
\hline & $\boldsymbol{B}$ & $\boldsymbol{B} \boldsymbol{t}$ & $\boldsymbol{S}$ \\
& & $\boldsymbol{T A}$ & \\
\hline ( Constant) & $\begin{array}{r}1.65 \\
3\end{array}$ & & $\begin{array}{r}7.8 \\
82\end{array}$ & .000 \\
& & & & \\
\hline $\begin{array}{l}\text { Knowledge } \\
\text { gain }\end{array}$ & .267 & .5 & $\begin{array}{r}10 . \\
12 \\
66\end{array}$ & .000 \\
\hline
\end{tabular}




\section{International Journal of Business Management and Economic Review}

Vol. 3, No. 05; 2020

ISSN: 2581-4664

\begin{tabular}{|l|r|l|l|l|}
\hline $\begin{array}{l}\text { Knowledge } \\
\text { gain*size }\end{array}$ & $\mathbf{. 0 7 8 2}$ & & $\begin{array}{l}\mathbf{3 5 9} \\
\mathbf{6}\end{array}$ & $\mathbf{. 7 1 9 5}$ \\
\hline (Constant) & $\begin{array}{r}2,06 \\
6\end{array}$ & & & .000 \\
\hline $\begin{array}{l}\text { Extension of } \\
\text { network }\end{array}$ & .467 & $\begin{array}{l}.4 \\
89\end{array}$ & $\begin{array}{r}8.2 \\
50\end{array}$ & .000 \\
\hline $\begin{array}{l}\text { Extension of } \\
\text { network *size }\end{array}$ & $\mathbf{. 1 8 3 1}$ & & $\begin{array}{l}- \\
\mathbf{1 . 1 4 9} \\
\mathbf{5}\end{array}$ & .2516 \\
\hline
\end{tabular}

a. Dependent Variable: GI

\subsection{Hypothesis 1 Results and Discussion}

Objective one determined the role of link to idea generation and micro and small enterprises growth. The support on idea generation from exhibition was determined as to fulfil the first objective

As displayed in Table 6, and Table 7 the regression model demonstrates a robust fitness of $\mathrm{R}$ Square .320 and F-value of 102.415 at $\mathrm{p}=$ value $.000^{\mathrm{b}}$. About $32 \%$ of the variation on micro and small enterprise growth indicators changes explained by knowledge gain in exhibition one percentage level change. With descriptive figures from Table 3, Table 4ab and 5 the results support the alternative hypothesis that the knowledge gained on exhibition has a positive relationship on micro and small enterprises growth.

As opposed to possibility of leaving owner's at isolation without knowledge and technology for knowledge gain, from exhibition it have a relative percentage in economic significant contribution on MSE's sales, product and services provision and formalization.

Business growth also called firm growth, means increase in firm's size from one period to another possibly where business gets more networks (Penrose, 1959: Premaratne2002: Bentezen et al, 2012; Schwabs et al, 2017). As firm growth theory asserts that, through experiences, managers learn new and more effective ways of combining resources to expand the productive sets. That ability to recognise and to absorb valuable information by assimilate and apply to commercial ends results in expansion of resources (Pernrose,1960: Nason \& Wiklud,2015).

In line with hypothesis one results Wold bank,(2016) indicate basic sales skills and capability building provision during MSE's exhibitions to owners to improve owners knowledge and hence income. It is also important for firms with resources constrain to associate with support that facilitate exhibitions as they will be equipped with techniques on how to keep breast with clients, ability to communicate, competitors action analysing as well how to keep eyes on technology changes in market from global perspective for growth to happen (Sindik,2012).

The findings is however in contrary with some empirical views that indicates MSE's to regrets exhibition usefulness as it hampers expectation due to poor organization of the events and language barrier among local participating exhibitors. Ummulkulthoum1 and Jianhua, 2017 : 


\section{International Journal of Business Management and Economic Review}

Vol. 3, No. 05; 2020

ISSN: 2581-4664

Imran et al., 2017, were of the opinion that event not intended for them and that organisers are more focused towards income generation as opposed to giving promotion opportunity to MSE's firm participants.

Moreover relationship to $\mathrm{H} 1$ is in consistence with Enablis, 2015; Mbura and Bambaganya,2015 which reports offering new ideas, means and technical through customized exhibitors needs in trading. It is also noted, ideas from the exhibition to be access to raw materials, markets, distribution, packaging, future exhibitions training, seminars, assistance, and others ( $\mathrm{Ni}$ et al.,2019).

The art of selling, presentations skills and product demonstrations are part of training due to lack of knowledge in sales skills for business to take advantage of exhibition and trade fair opportunities. Other services is to provide capacity building and orientation on how exhibitors need to concentrate on attraction of most profitable clients in a short term but also focusing on long-term commitments (Ummulkulthoum1 and Jianhua, 2017).

H1 is, however, supported by Yahya and Muturumbukwa, 2015 as they assets MSE's capabilities to meet the requirements to be necessary from supporting institutions by providing information on markets during trade exhibitions being regional and international markets. That various stakeholders might have, and explores how their interests are furthered and protected in dealings with each other in various business contexts including fair trade and exhibition.

This is an important venue for learning where micro and small business owners acquire new knowledge, technologies, new markets for goods and trainings from other stakeholders at low costs, the efforts that compliments MSE's resources constrains in creating new resources or its economic value (Haider et al., 2017).

The facilitation assist low costs in accessing information from various government and non government entities on services they provides in supporting businesses like publications, training, trade fairs linkages and other programs. The information may be for specific industry or generally. The exposures to relevant associations for afflictions is also one of the outcome of trade and fair facilitation (Hatten,2012: Skurczyńska,2018).

\subsection{Hypothesis 2 results and discussion}

As displayed in Table 6, and Table 7 the regression model demonstrates a robust fitness of $\mathrm{R}$ Square .240 for network extension and F-value of 68.055 at $\mathrm{p}=$ value. $000^{\mathrm{b}}$. About $24 \%$ of the variation on micro and small enterprise sales, product or services and formalization was explained by network extension. With descriptive figures from Table 3, Table 4ab and 5 the results support the alternative hypothesis that the extension of network on the exhibition has a positive relationship on micro and small enterprises growth..

The positive influences toward MSE's growth is in line with McMahon, 2007; Hatten, 2012 who assert that, managers and owners, owner-managers and others like, insiders (primarily owner-managers, other owners and managers) and outsiders need to be aliened together with other business actors which in the economy which create opportunity to access market for expansion. The tie may be come from the linkages to financing and non financing entities owners (Olawale et al,2018).

The MSE's also participating in trade fairs exhibitions and use door-to- door from the boot to boot and word- of- mouth during the events to foster a long term relationship with customers. 


\section{International Journal of Business Management and Economic Review}

Vol. 3, No. 05; 2020

ISSN: 2581-4664

The owners of the enterprises capitalize on this collaboration to receive feedback on their operations so as to improve on customer satisfaction (Ogundana, 2018: Diana and Ysabel,2019).. They also use discount sales and promotions to gain access to new customers and to entrench their brand in existing and new markets. These strategies generally help the SMEs to increase their profitability and brand awareness. These factors enable the SMEs to generate enough revenue to expand their businesses now or in the future after the events( Kllezi,2014: Aikael,2012).

In line with the finding extension of network to influences resources extension enable business owners to have the base for scanning external business environment. Kemp,2013 supports findings by asserts that, the network extension facilitates the increase of wide range of potentials customers, suppliers and investors that when presentation of products and services are done possibility of sales increases happen. It also a time where friends, fellow members, new customers link, suppliers link, investors and regulatory authorities for instant sales and future sales agreement to happens. The networking facilitation assists exposure to workshops with other organisation for provision of Market information (Lesuruan, 2018).

However Olawale, et al 2018 found prices of goods in exhibition very high compared with what is obtainable in the open market and also modern shops that discourages buyers. Another different view of network extension to positively influence MSE's growth is reported by Priyanath and Premaratne, 2014: Haider et al., 2017 that, many MSE's participants faces problem of competition during exhibitions mainly caused by the presence of large firms which also participate in the fairs. Such big firms are endowed with financial resource as well as technical knowhow. Due to that, they display products of better quality and more attractive compared to ones displayed by SMEs. Thus SMEs get very difficult time in promoting their products/services as well as establishing network (Diana and Ysabel, 2019).

Also influences on growth happen as results of creation of good image to the public due to established network MSE's get opportunity to be covered by media during the events. Such coverage, exhibitors explain about their firms, their offers, prices and other quality control issues. They also get an opportunity to invite prospective customers to business premises where coverage create new investors, and new customers are created. Such that when exhibitions are over, many people visit MSE's firms for business deals ( Haider et al., 2017; Imran et al., 2017: Olawale et al, 2018).

\subsection{Hypothesis 3 results and discussion}

In testing the interaction effect of size on knowledge gain and extension of network model fitness indicted possibility of growth variation to be $24 \%$ at the significant level $\mathrm{p}=$ value.9539, .2518 and $F$ value of 110.415 and 74.015 . indicating moderation effect absences. The results support the acceptance of null hypothesis that business size does not affect the relationships of at least one of two exhibition indicators and micro and small enterprises growth.

Size of business shows absence of affects on the relationship between trade exhibition variable and growth of micro and small enterprises. As proposed size should be identified as a moderating variable, and then studied its impact on the relationship between variables toward sustainable performance. The reasons for the results based on the facts that their ownership, control, and operation is often in the hands of an individual or a small group of individuals that may speed 


\section{International Journal of Business Management and Economic Review}

Vol. 3, No. 05; 2020

ISSN: 2581-4664

decision as coppared to larger with ability to plan for trade exhibition (Bamiatzi \& Kirchmaier, 2014; Getz \& Carlsen, 2000 : Wang, et al,2018). However their sizes may not directly affect the performance but influence the speed of pro-activeness, innovation, and performance as compared to larger and long established firms (Andreas \& Mike,2018 : Greene, et al., 2015.

That during trade exhibition if an enterprise has relatively bigger size, its risk taking and proactiveness would more significantly affect the performance (Haider et al., 2017c; Imran et al., 2017). Likewise, if the size of an enterprise were large, it would be more prone to innovativeness as it has the capacity to face any failure (O'Regan \& Ghobadian, 2004 : Weiermair \& Peters, 1998).

On contrary, micro and small business may display flexibility originating from their sizes (Bamiatzi \& Kirchmaier, 2014; Getz \& Carlsen, 2000) as opposed to lager business that will need various formal procedures to decide on pursuing a certain strategies. On other hand micro and small firms might face difficulties in either implementing proactive efforts due to limited resources (Andreas \& Mike, 2018) on expected margins, or that they simply do not have the financial means to exploit these proactive capabilitiesduring trade exhibition (Weiermair \& Peters, 1998). That large companies characterized by flexibility and discretion or prudency perform better that those emphasising stability order. The evidence on performance may be seen on how the micro and small enterprises growth rate increases faster than large firm( Pedersen et al,2016: Ramalho, et al, 2018) .

\section{CONCLUSION}

Trade exhibition to MSE's is a veritable marketing communications strategy for exposing the prospective and current products and services to customers. It establishes an avenue for the varied customers to meet one on one for exchange ideas, knowledge, money and industrial/consumer goods and services. Through trade exhibition the knowledge gained has shown positive influences on MES's resource expansion. Other variable were extension of network on growth which indicated positive influences on the relationship. However sizes of business indicted not to affect the relationship in the construct. In the light of this study more investigation is encourages to cover more variables using qualitative approach

\section{REFERENCES}

Abonneau, D., \&Campoy, E., (2012). Mentor et protégé durant la phase d'initialisation de la relation: fonctions centrales et conséquences, Economics Papers from Paris Dauphine University.

Aikaeli, J. (2012). Improving competitiveness for SMEs to harness available trade and investment opportunities: The case of Tanzania. Huria: Journal of the Open University of Tanzania, 11(1), 25-43.

Aislabie, C.,(1992 ). "Sudden Changes in a Model of Small firm Growth", Small Business Economics, 4(4), 307-314.

Akman and Dagdeviren,(2018).Discovering What Makes a SME Website Good For International Trade, Technological and Economic Development of Economy, ISSN 2029-4913 / eISSN 2029 4921, Volume 24 Issue 3: 1063-1079, Anderson, B. S., \& Eshima, Y. (2013). The influence of firm age and intangible resources on the relationship between 


\section{International Journal of Business Management and Economic Review}

Vol. 3, No. 05; 2020

ISSN: 2581-4664

entrepreneurial orientation and firm growth among Japanese SMEs. Journal of business venturing, 28(3), 413- 429.

Anderson, W. (2012). "A gender - Based Comparison of Marketing Strategies of SMEs in Tanzania". International jounal of Marketin Principles and Practices, Volume Issue 1. p 32-42. Anderson, W. (2017). Factors Affectin Small \& Medium Enterprises (SMEs) Start- up and Growth in Tanzania. The Pan-African Journal of Business Management, [onlin 1(1), pp.1-51. Andreas K. \& Mike, P. (2018) Entrepreneurial Behavior Firm size and Financial Performance: the Case of Rural Tourism Family Firms, Tourism Recreation Research, 43:1, 2-14, Anna, (2018). Support measure for Internationalization of Europe SMEs-Comparative analysis. Ekonomiczne Problemy Usług nr 3/2018 (132) ISSN: 1896-382X | www.wnus.edu.pl/epu DOI: 10.18276/epu..132-05 | strony: 55-67.

Anis B. S, and Lassaad L, (2018) "Entrepreneurial coaching: how to be modeled and measured?", Journal Management Development, Vol. 37 Issue: 1, pp.88-100, https://doi.org/10.1108/JMD-12-2016- 0292,Permanent link to this document:

Ansah, J. K. (2017). Strategic Planning and Performance of Micro and Small Family Businesses in Ghana. The Resource Based Approach (Doctoral dissertation).

Anton, S. G., \& Onofrei, M. (2016). Public Policies to Support Entrepreneurship and SMEs. Empirical Evidences from Romania. Transylvanian Review of Administrative Sciences, 12(47), 5-19.

AUMA, (2013). The German trade fair industry: facts, function, outlook Retrieved from https:// auma.de/en/DownloadsPublications/.Bamiatzi, V. C., \& Kirchmaier, T. (2014). Strategies for superior performance under adverse Conditions: A focus on small and medium-sized highgrowth firms. International Small Business Journal, 32(3), 259-284. doi:10.1177/0266242612459534.Bentzen, J., Madsen, E. S., \& Smith,V., (2012). Do firm's growth rates depend on 011- 9341- 8 .

Crompton .,M.B,.(2012), The Effect of Business Coaching and Mentoring on Small-toMedium Enterprise Performance and Growth, PhD Dissertation, School of

Management, College of Business, RMIT University, Melbourne, Australia.

Diana.N., Ysabel, N, K.,(2019). The Changing Role of International Trade Shows in Today's Internationalisation Process of SMEs: an Application to SMEs in the Diamond Sector Journal of Creativity and Business Innovation, Vol. 5, www.journalcbi.com ISSN 2351-618.

Dzisi, S., \& Ofosu, D. (2014). Marketing nstrategies and the performance of SMEs in Ghana. Marketing, 6(5), 102-111.

Enablis,(2015). The enablisentrepreneurial network Tanzanaia Chapter annual report

Getz, D., \& Carlsen, J. (2000).

Characteristics and goals of family and owner-operated in the rural tourism and hospitality sectors. Tourism Management, 21(6), 547-560. doi:10. 1016/S0261- 5177(00)00004-2.

Greene, P. G., Brush, C. G., \& Brown, T. E. (2015). Resources in small firms: An exploratory study. Journal of Small Business Strategy, 8(2), 25- 40.

Hatten ,T.,(2012). Small Business Management Entrepreneurship and Beyond (5th edition) . Canada: Mesa State College.

Imran, M., Aziz, A \& Hamid, S. (2017). Determinants of SME export performance. International Journal of Data and Network Science, 1(2), 39- 58. 


\section{International Journal of Business Management and Economic Review}

Vol. 3, No. 05; 2020

ISSN: 2581-4664

Lesuruan, M., N. \& Kihara, A. (2017). Effect Of Mentorship On Growth Of Small And Medium Enterprises In Kenya: A Case Of Kilimo Consumers Cooperative Society. International Journal of Human Resources and Procurement. Vol. 6 (5) pp 455 - 473 Lesuruan, M. (2018). Effect of Mentorship on Growth of Small and Medium Enterprises in Kenya: A Case of Kilimo Consumers Cooperative Society.

Journal of International Business, Innovation and Strategic Management, 1(2), 21-40. Loewe,M.,AlAyouty,I.,Altpeter,A.,Borbein,L.,Chantelauze,M.,Kern,M.,\&Reda,M (2013).Which Factors Determines the Upgrading of Small and Medium Sized Enterprises (SMEs) ? The case of Egypt.

Lufumbi.J.M (2009). Business research Methodology, 3th edition. Haider, S. H., Asad, M., Fatima, M. \& Abidin, R. Z. U. (2017c). Microfinance and performance of micro and small enterprises: Does training have an impact. Journal of Entrepreneurship and Business Innovation, 4(1), 1-13.

Hayes, A. F. (2012). PROCESS: A

Versatile Computational Tool for Observed Variable Mediation, Moderation, and Conditional process Modeling [White paper]. Retrieved From http://www.afhayes.com/public/process.

Kazungu, I., Ngugi, P. K., Rotich, G., \& Otieno, R. O. (2018). The artisans: Examining the influence of Entrepreneurship Training on the Performance of Handicraft Exporting Micro and Small Enterprises in Tanzania. International journal of Economics, Business and Research, Volume 2,No,01.

Kellezi, J. (2014). Trade shows: a strategic marketing tool for Global Vompetition. Procedia Economics and Finance, 9, 466-471.

Kellezi, J. (2013). The effectiveness of trade shows in global competition. European Academic Research, 1(3), 265-274.Kemp, P.(2013).The Influence of Business Incubation in Developing new

Enterprises in Australia, Edith Cowan University.

Krauss, S. E. (2005). "Research Paradigms and Meaning Making A Primer" The Qualitative Report , X (4), 758-770.

Kirchgeorg, M., Springer, C., \& Kästner, E. (2009). Objectives for successfully participating in trade shows. Journal of Business \& Industrial Marketing, 25(1), 63-72.

Kreivi, M., Wang, L., Muhos, M., \& Kess, P. (2012). Trade Fairs and Networking-SMES Internationalizing in China. Journal of US-China Public Administration, 9(5), 516-533

Kule ,J.W,.(2014). An assessment of organization factors affecting performance of Manufacturing small and medium Enterprises.

Evidence From Kampala Uganda. A thesis submitted in fulfillment of the requirement for the degree of Doctor of Philosophy in Business Management of the Open University of Tanzania.

Machado, H. P,. V. (2016). Growth of Small Businesses: A Literature Review and Perspectives of Studies. Crescimento de pequenas empresas: revisão de literatura e perspectivas de estudos . Gest. Prod., São Carlos, v. 23, n. 2, p. 419-432 .

Mbura, O. K., \& Bambaganya, M. W. (2016).

Success and usefulness of business development services in Tanzania's SMEs Market. Business Management Review, 18(2).

McMahon R. G.P. (2007), Ownership structure, business growth and financial performance amongst SMEs, From Australia's business longitudinal survey Mori, N. (2014). Women's Entrepreneurship Development in Tanzania: Insights and Recommendations / International Labor Office -Geneva: ILO. 


\section{International Journal of Business Management and Economic Review}

Vol. 3, No. 05; 2020

ISSN: 2581-4664

Mulyantinia,S,. Hidayatia,S. Marlinaa,(2020).The Strategy of SMEs/SMIs Development in DKI Jakarta Hasanuddin Economics and Business Review 03:3 (2020) 86-102, A Faculty of Economics and Business, Universitas Pembangunan Nasional Veteran Jakarta.

Mungai,B.(2012). The Relationship Between Business Management Training and Small And Medium-Sized Enterprises' Growth in Kenya, PhD Thesis Kenyatta University.Nason, R. S., \& Wiklund, J. (2018). An assessment of resource-based theorizing on firm Growth and Suggestions for the future. Journal of Management, 44(1), 32-60.

Ni. N. S, Maranatha, W., Kukuh, L., Yoseph, B,. K, M,. Farid, A,.(2019).

Community As A Driver Of Smes Growth In Indonesia, INTERNATIONAL JOURNAL OF SCIENTIFIC \& TECHNOLOGY RESEARCH VOLUME 8, ISSUE 10, OCTOBER ISSN 2277-8616 2740 IJSTR www.ijstr.org Nyamagere, S. G., \& Nchimbi, M. I. (2018). Insights on Impact of Business Development Services on Growth of Women Owned Enterprises in Tanzania. Journal of Management and Strategy, 9(1), 82-93.

Ogundana,O., Kostas G., Amon, S., and Lynn O.(2018).Factors Influencing the Business Growth of Women-Owned Sewing, Businesses in Lagos-State, Nigeria: A Pilot Study, Organisational Studies and Innovation Review Vol. 4, no.2, Olawale, Y. A., Salman, A., abdulraheem, M.,(2018).

Trade Exhibition and Small and Medium Scale Enterprises Development: Study of Selected SMEs in Ilorin, Kwara State.Olom, D. (2003).

Entrepreneurship and Small business Development, A Tanzania Perspectives, UDEC.Olomi, D.\& Mori, N.(2015).Lesson From Equity Financing : Experience of Tanzania. Institute of Management and Entrepreneurship development.

Osei, A., Forkuoh, K. S., Shao, Y., \& Osei, M. A. (2016). The Impact of Institutional Support in SMEs Marketing, and Growth-A Case Study of Retail SMEs in Ghana. Open Journal of Business and Management, 4(03), 408.O'Regan, N., \& Ghobadian, A. (2004).

Testing the homogeneity of SMEs: The impact of size On managerial and organisational processes. European Business Review, 16(1), 64 - 77.

Pedersen,E.R.G., Gwozdz, W., Hvass,K.K.,(2016). Exploring The Relashioship Between Business Model, Innovation, Corporate Sustainability, and Organisational, Value with The Fasion Industry. Jounal of Ethics, Copenhagen Business School.

Penrose, E. (1959). Theory of the Growth of Firm. Oxford: Basil Blackwell, third edition.

Pervan, A.and Višić, J.(2012), Influence Of Firm Size On Its Business Success E-mail: josipa.visic@efst.hr--Croatian Operational Research Review (CRORR), Vol. 3, Pradana, M. (2016). The Usefulness of Online Platform to Increase Small Medium Enterprise (SME)'s Performance (Case Study: Qlapa Indonesia). Белокрылова ОС-д. э. н., профессор, заслуженный деятель науки РФ, профессор кафедры экономической теории ФГАОУ ВО «Южный федеральный университет» Стрельиова ЕД-д. э н., профессор, ФГБОУ ВПО «Южно-Российский государственный политехнический университет (НПИ) им. МИ Платова, 388.

Premaratne.S.P.(2002). Entrepreneurial Networks and Small Business Development (the case of Small Enterprises in Sir lanka). Universities Eindhoven- Proefschrift.

Priyanath, H. M. S., \& Premaratne, S. P. (2014). Government SME development programs in Sri Lanka: A review in the lens of transaction cost economics. Sabaragamuwa University Journal, 13(2), 59-81.

Ramaciotti, L., Muscio, A., \& Rizzo, U. (2017). The impact of hard and soft policy measures 


\section{International Journal of Business Management and Economic Review}

Vol. 3, No. 05; 2020

ISSN: 2581-4664

on new technology-based firms. Regional Studies, 51(4), 629-642.

Rennemo L. and W. M Bogren , (2017)," Business growth through intentional and nonIntentional network processes ", Journal of Small Business and Enterprise Development, Vol. 24 Iss 2 pp. - Permanent link to this document:, http://dx.doi.org/10.1108/JSBED-08- 20160131.

Ramalho, J. J. S., Rita, R. M. S. \& da Silva, J. V. (2018). The impact of family ownership on capitalstructure of firms: exploring the role of zero-leverage, size, location and the global financial crisis. International Small Business Journal.

Rim, B. A. M.and Monia, G.(2018).Growth of Micro, Small and Medium enterprises (MSMEs) in MENA countries: constraints and success factors EMNES Working Paper No 5

Saidi ,A., Abideen,A.,T. (2018).Effect of Support for Entrepreneurship Development on Economic Growth and Development in Nigeria, European Scientific Journal May edition Vol.13, No.13 ISSN: 1857 - 7881 (Print) e - ISSN 1857- 7431.

Sarr, L. (2019). Particularity of informal Senegalese SMEs and Challenges of Their Formalization. International Journal of Business and Social Science, 10(10).

Sasaka, P. S. (2012). The Effectiveness of Trade Shows and Exhibitions as Organizational Marketing Tool, (Analysis of Selected Companies in Mombasa). International Journal of Business and Social Science, 3(22).

Saunders,M. N. K., Lewis, P. \& Thornhill, A., (2016). Business research for business students (7th edition). Harlow: Pearson Education Ltd Schwab, L., Gold, S, Kunz, N. \& Reiner, G. (2017). "Sustainable Business Growth: Exploring Operations Decision-Making" Journal of Global Responsibility, doi: 10.1108/JGR-11- 2016-0031.

Sidik ,I.G.(2012). Conceptual framework of factors affecting SME development: Mediating factors ob the realationship of entrepreneurs traits and SME performac. Internatinal Conferences on small and Medium Entreprises Development with a Theme "Innovation and sustainability in SME development".

Procedia Economics and finance 4, 373-383.Sharafizad J, Coetzer A (2017). Women business owners' start-up motivations and network structure, Journal of Management \& Organization, 23(2): 206-223.SME,(2003). Small and Medium Enterprises Policy Stokes ,D \& Wilson.(2010) Small Business Management and Entrepreneurship, 6th Edition, South Western.

Terefe, S. M.(2018). Assessment of Factors Affecting the Success of Micro and Small Scale Enterprises in Ethiopia:(Case of Debre Markoss Town) International journal of Research in Management, Economics and Commerce, ISSN 2250-057X,Impact Factor:6.384,V.08 issue 04, P158-163.

Von Friedrichs, Y. and Rennemo, Ø. (2013), Kvinners Foretak og Foretakende KvinnerVekstentreprenører i Skandinavia (Women Enterprises and Enterprising Women, Growth Oriented Entrepreneurs in Scandinavia), Akademika Forlag, Trondheim.

Udomkit, N., \& Schreier, C. (2017). Tie the ties: The significance of the binding networks in SMEs' internationalization process. Journal of Asia-Pacific Business, 18(1), 4-20

Ummulkulthoum, A., \& Jianhua, Y. (2018)The Challenges Facing Small and Medium Enterprises (SMEs) Participating in Trade Fair: A Case of Dar es Salaam International Trade Fair (DITF) in Tanzania.

International Journal of Managerial Studies and Research, V5,Issue,12, P26-34.Wang, J., Zhang, 


\section{International Journal of Business Management and Economic Review}

Vol. 3, No. 05; 2020

ISSN: 2581-4664

Y., \& Goh, M. (2018).

Moderating the role of firm size in sustainable performance improvement through sustainable supply chain management. Sustainability, 10(5), 1654.Weiermair, K., \& Peters, M. (1998). The internationalization behaviour of small-and medium-sized service enterprises. Asia Pacific Journal of Tourism Research, 2(2), 1-14. doi:10. 1080/10941669808721992.Willemse, A. K. (2018). The moderating effect of mentorship on enterprise development in South Africa (Doctoral dissertation).

World bank group, (2016). Growing Agribusiness SMEs in Tanzania. 1818 H Street NW, Washington ,DC 20433

World Bank,(2014) Global Financial Development Report; Financial Inclusion, World Bank, Washington DC.

Woodward, J. (1965). Industrial : Theory and Practice, Oxford University Press.Yahya,.M. and Mutarubukwa,P.(2015).

Capacity of Tanzania Micro and small and Medium Enterprises In Tapping The business opportunity in East Africa Community. Busines Education Jounal, vol,1 Issue,1-20p. 